\title{
VALUE OF SPEED CAPABILITIES IN YOUTH SPEED CLIMBING AT HIGH SPORTS LEVEL
}

\author{
Marcin Krawczyk \\ Faculty of Health Sciences, University of Applied Sciences in Tarnow, Poland \\ Mariusz Pociecha \\ Faculty of Health Sciences, University of Applied Sciences in Tarnow, Poland \\ Mariusz Ozimek \\ Institute of Sport, National Research Institute, Warsaw, Poland
}

Aleksandra Stepek

Faculty of Health Sciences, University of Applied Sciences in Tarnow, Poland

Paulina Kozioł

Faculty of Health Sciences, University of Applied Sciences in Tarnow, Poland

\begin{abstract}
Current research on speed climbing at the senior level shows that speed capabilities are a significant factor determining climbing time. The main purpose of our research was to evaluate the level of speed capabilities among young speed climbers and to examine the relationship between the level of speed capabilities and the results achieved during an international competition. The subjects of the research were girls and boys in the following age categories: Female Youth A (age=16.6), Female Youth B (age=14.5 years), Male Youth A (age $=16.87$ years) and Male Youth $B$ (age $=14.8$ years). Measurements of somatic features were included: body height, body weight, percentage of fat tissue and BMI. Speed capabilities were measured with Wingate Test. The significance test of differences showed no significant differentiation within climbing times between the groups of girls and the groups of boys. A strong correlation between climbing time and relative peak power was noticed in the Female Youth B group. The correlation between peak power and climbing time was lower in the other groups. Research showed that in speed climbing, as career progresses, it is importance of other factors rather than speed capabilities that may increase. It can be assumed that with an increase in training experience, motor skills become more essential.
\end{abstract}

Keywords: speed capabilities, speed climbing, youth categories, Wingate Test.

\section{Introduction}

Sport climbing can be considered in three forms: speed climbing, bouldering and difficulty climbing. Each of these disciplines involves different types of effort and a different role for the upper and lower limbs. Speed climbing consists in covering the competition distance in the shortest possible time. Current research indicates that in speed climbing the important motor factors determining sports 
success are: a high level of explosive strength and a high level of lower limb muscle power (Krawczyk, Ozimek, \& Rokowski, 2015; Krawczyk, Ozimek, Rokowski, Pociecha, \& Draga, 2017; Krawczyk \& Ozimek, 2014; Krawczyk, Ozimek, Rokowski, Pociecha, \& Draga, 2018). Some studies have shown that body proportions can be of considerable importance in sport climbing (Ozimek et al., 2017; Tomaszewski, Gajewski, \& Lewandowska, 2011). Most of the research has been conducted among competitors at the senior level. Compared to the number of studies among senior climbers, there are much fewer of them pertaining to youth (or child) groups. These, in turn, mainly concerned bouldering and difficulty climbing, and mainly addressed the following issues: the impact of the level of somatic features of young climbers (Watts, Joubert, Lish, Mast, \& Wilkins, 2003) determination of the profile of specific motor skills in children practising sport climbing (Nichols et al., 2018), oxygen uptake during climbing in children (Watts \& Ostrowski, 2014), factors determining the effectiveness of climbing in bouldering (Votava, Matej, Otahal, \& Kutilek, 2018), the impact of climbing training on the body composition and level of strength of the upper limbs (Baláš, Strejcová, Malý, Malá, \& Martin, 2009) and specific reactions to climbing training in children (Morrison \& Schoffl, 2007).

In groups of young climbers specializing in speed climbing, it is the Shulga's study that deserves attention, as it assessed the relationship between fitness preparation and the results obtained in speed climbing competitions in children aged 14-15 years (Shulga, 2010). Analysis of the literature shows that there is little scientific research in groups of young sports climbers. In this context, it seems reasonable to measure the physical fitness of young speed climbers. The results of these tests can be a valuable tool for the work of coaches.

The main purpose of this research was to assess and analyse the level of strength and speed capabilities of young competitors, participants of the European Junior Cup in speed climbing. In our own analyses, an attempt was made to estimate the impact of strength and speed potential on the results achieved. Based on the available state of scientific knowledge and in the context of achieving the objectives of this study, the following research questions were posed:

1. What is the level of strength and speed potential of young competitors participating in speed climbing at an international level?

2. What is the relationship between the results of fitness test and the best climbing time achieved?

3. What is the relationship between motor potential and climbing time depending on the age category or sex of the competitors? 
SOCIETY. INTEGRATION. EDUCATION

Proceedings of the International Scientific Conference. Volume VI, May $22^{\text {th }}-23^{\text {th }}, 2020.264-272$

\section{Material and methods}

The research included 26 competitors participating in the speed climbing competition during the European Junior Cup, held in Tarnów, in May 2017. The competition was conducted in accordance with the regulations of the International Federation of Sport Climbing (IFSC). The competitors surveyed competed in the categories: Female Youth A (group F1, calendar age $=16.6$ years, $n=5$ ), Female Youth B (group F2, calendar age $=14.5$ years, $n=8$ ), Male Youth A (group M1, calendar age $=16.9$ years, $\mathrm{n}=8$ ) and Male Youth $\mathrm{B}$ (group M2, calendar age $=$ 14.8 years, $n=5$ ). All the surveyed competitors and their guardians had been informed about the aims and course of the voluntary research. All measurements were taken after the competition.

Somatic measurements included: body height $(\mathrm{BH})$, body weight $(\mathrm{BW})$, body fat percentage (\% FM), and Body Mass Index (BMI). For this purpose, an anthropometer and the TANITA scale model BF-350 were used. The measurements were based on ISAK standards (Stewart, Marfell-Jones, \& International Society for Advancement of Kinanthropometry, 2011). Motor efficiency was evaluated with the use of the Wingate test. For this purpose, a Monark 874E cycloergometer with MCE v 5.2 software was used. The test protocol presented by Nikolaidis et al. (Nikolaidis, Afonso, Buśko, \& Ingebrigtsen, 2015) was used. In the tests conducted, the external load in the F1 and F2 groups amounted to $7.5 \%$ of body weight whereas in the M1 and M2 groups - to $8 \%$ of body weight. The test time was 30 seconds and started from the "0" position, i.e. from freeze position. The following basic parameters were recorded in the test: relative work total Wtot [ $\mathrm{J}$ and $\mathrm{J} / \mathrm{kg}]$, which enables anaerobic capacity assessment, i.e. the ability to develop maximum anaerobic lactic acid capacity; PP power peak [W and $\mathrm{W} / \mathrm{kg}$ ], which informs about the maximum mechanical muscle power, i.e. the ability to develop maximum non-acid lactic anaerobic capacity. In addition, the following supplementary indicators were recorded: time to reach the power peak (Time to PP [s]), indicator of power decrease (WS\% P [\%]), capacity indicator of the ATP-PCr system [s], which was calculated as the sum of the time needed to reach and maintain the maximum pedalling frequency. In the statistical processing of data the following were used: descriptive statistics, Shapiro-Wilk test; Student's t-test and Mann-Whitney U test, and the Pearson and Spearman correlations.

\section{Results}

Table 1 shows the average values of the measurements conducted during the research. It should be noted that the average climbing time did not differentiate between the female and the male groups. The values of $\mathrm{p}$ indicators in the 
significance tests were: 0.10 in female groups, and 0.70 in male groups, respectively. Statistically significant differences were noted in the female groups with respect to LBM, Wtot [J], and PP [W]. The male groups were statistically significantly different in terms of body weight, LBM ( $<<0.01)$, Wtot $[\mathrm{J}]$, and PP [W]. Other variables did not differentiate the groups under examination.

Table 1 Descriptive characteristics and analysis of intergroup differences in the examined indicators of somatic structure and motor efficiency

\begin{tabular}{|c|c|c|c|c|c|c|c|c|}
\hline \multirow{2}{*}{ variable/group } & \multicolumn{2}{|c|}{ F1 } & \multicolumn{2}{|c|}{ F2 } & \multicolumn{2}{|c|}{ M1 } & \multicolumn{2}{|c|}{ M2 } \\
\hline & $\mathrm{X}$ & sd & $\mathrm{X}$ & sd & $\mathrm{X}$ & sd & $\mathrm{x}$ & sd \\
\hline best time [s] & 10.12 & 1.12 & 11.31 & 1.56 & 8.07 & 1.05 & 9.36 & 1.91 \\
\hline $\mathrm{BM}[\mathrm{kg}]^{1}$ & 52.94 & 5.04 & 51.03 & 9.66 & 69.38 & 5.23 & 62.35 & 6.40 \\
\hline $\mathrm{BH}[\mathrm{cm}]$ & 159.62 & 3.37 & 159.11 & 7.40 & 176.62 & 8.22 & 169.68 & 3.03 \\
\hline FM\% & 19.14 & 6.09 & 21.49 & 6.80 & 11.54 & 2.11 & 11.56 & 2.41 \\
\hline LBM [kg] $]^{2.3}$ & 42.56 & 1.18 & 39.59 & 4.64 & 61.34 & 4.30 & 55.06 & 4.89 \\
\hline BMI & 20.79 & 1.98 & 20.00 & 2.08 & 22.29 & 1.87 & 21.61 & 1.59 \\
\hline $\mathrm{W}_{\text {tot }}[\mathrm{J}]^{1.2}$ & 12009.76 & \begin{tabular}{|l|}
1334.07 \\
\end{tabular} & 10413.08 & \begin{tabular}{|l|}
2797.72 \\
\end{tabular} & 19661.38 & \begin{tabular}{|l|}
1220.98 \\
\end{tabular} & 16716.91 & 2121.51 \\
\hline $\mathrm{W}_{\text {tot }}[\mathrm{J} / \mathrm{kg}]$ & 226.98 & 15.60 & 203.19 & 25.96 & 283.76 & 10.51 & 267.89 & 17.33 \\
\hline $\mathrm{PP}[\mathrm{W}]^{1.2}$ & 519.94 & 63.54 & 446.11 & 109.75 & 850.70 & 58.40 & 719.21 & 94.43 \\
\hline $\mathrm{PP}$ [W/kg] & 9.81 & 0.45 & 8.73 & 0.98 & 12.29 & 0.75 & 11.52 & 0.79 \\
\hline time to PP [s] & 8.91 & 2.24 & 8.82 & 2.38 & 5.74 & 0.43 & 5.96 & 1.28 \\
\hline WS\%_P [\%] & 20.09 & 6.78 & 20.55 & 4.99 & 22.18 & 2.62 & 21.53 & 3.40 \\
\hline $\begin{array}{l}\text { ATP-PCr } \\
\text { system [s] }\end{array}$ & 9.82 & 2.37 & 10.30 & 2.59 & 7.79 & 0.51 & 7.65 & 1.99 \\
\hline
\end{tabular}

Explanatory note: ${ }^{1}$ - statistically significant difference of $p<0.05$ between groups M1 and M2; 2 - statistically significant difference of $p<0.05$ between F1 and F2; ${ }^{3}$ - statistically significant difference of $p<0.01$ between groups M1 and M2

Table 2 shows the correlation coefficients between the best climbing time and the other variables. In group F2, a significant correlation was noted between climbing time and PP power peak [W / kg]. Other correlations were insignificant. Analysing the correlation results, it can be observed that in group F1 the correlation of climbing time and PP [W / kg] is lower when compared to group F2. It may indicate that in the upper age category the maximum anaerobic power is not the most important factor determining climbing time. A similar regularity occurred in groups M1 and M2, where the strength of the relationship of this indicator (PP [W / kg] with climbing time was weak, which may indicate that among boys, at this level of competition, the level of maximum anaerobic power is not the most important and the only determinant of the climbing time achieved.

Regularities in the correlations between climbing time and efficiency indicators in Wingate tests were also observed. In both groups of higher age categories, especially among girls, the $\mathrm{W}_{\text {tot }}$ coefficients $[\mathrm{J} / \mathrm{kg}]$ are higher, which indicates an important role of anaerobic acid-lactic power in achieving high 
SOCIETY. INTEGRATION. EDUCATION

Proceedings of the International Scientific Conference. Volume VI, May $22^{\text {th }}-23^{\text {th }}, 2020.264-272$

results. In addition, in group M2 strong but statistically insignificant correlations between climbing time and the level of somatic features were observed.

Table 2 Values of correlation coefficients between climbing time and the level of measured somatic features and motor efficiency indicators

\begin{tabular}{|c|c|c|c|c|}
\hline Variable/group & F1 & F2 & M1 & M2 \\
\hline best time [s] & 1.00 & 1.00 & 1.00 & 1.00 \\
\hline $\mathrm{BM}$ [kg] & 0.42 & 0.14 & -0.01 & -0.68 \\
\hline $\mathrm{BH}[\mathrm{cm}]$ & -0.26 & -0.07 & 0.02 & -0.54 \\
\hline FM\% & 0.49 & -0.02 & -0.32 & -0.46 \\
\hline LBM [kg] & 0.14 & 0.19 & 0.09 & -0.70 \\
\hline BMI & 0.55 & 0.17 & -0.05 & -0.71 \\
\hline $\mathrm{W}_{\text {tot }}[\mathrm{J}]$ & -0.18 & -0.17 & -0.32 & -0.66 \\
\hline $\mathrm{W}_{\text {tot }}[\mathrm{J} / \mathrm{kg}]$ & -0.84 & -0.62 & -0.49 & -0.24 \\
\hline $\mathrm{PP}[\mathrm{W}]$ & 0.15 & -0.60 & -0.18 & -0.66 \\
\hline $\mathrm{PP}[\mathrm{W} / \mathrm{kg}]$ & -0.44 & $-0.71^{1}$ & -0.26 & -0.30 \\
\hline time to $\mathrm{PP}[\mathrm{s}]$ & -0.56 & 0.40 & -0.09 & 0.46 \\
\hline WS\%_P [\%] & 0.62 & 0.10 & 0.42 & -0.47 \\
\hline ATP-PCr system [s] & -0.65 & 0.50 & -0.11 & 0.45 \\
\hline
\end{tabular}

Explanatory note: ${ }^{1}$ - statistically significant correlation at $p<0.05$

\section{Discussion}

In the light of the analysis of scientific reports, the present study, conducted on the basis of a series of observations of participants of the European Junior Cup competition, is the first attempt to assess the motor potential of the leading young speed climbers in the European ranking. The Wingate test was used to assess and analyze the motor potential of the climbers under examination. To date, the Wingate test has rarely been used in groups of climbers (Magiera et al., 2013; Mermier, Janot, Parker, \& Swan, 2000). This may be due to the fact that these tests are not specific to climbing, and therefore the assessment of climbers' fitness and efficiency should be conducted with the use of more specific tests (Michailov, Morrison, Ketenliev, \& Pentcheva, 2015). Nevertheless, cycloergometric tests provide reliable information on anaerobic performance (strength and speed efficiency) and are still widely used in high-level youth sport (Bozic \& Berjan Bacvarevic, 2018; Carvalho et al., 2011; Nikolaïdis, 2012). Research conducted among sport climbers has enabled the development of their motor profile. In lead climbing or bouldering, the most important predispositions and abilities conducive to achieving good results are similar (Levernier, Pierre, \& Laffaye, 2020; Michailov, Mladenov, \& Schoeffl, 2009; Ozimek et al., 2017; Watts, 2004). In speed climbing, the motor profile is different. It is determined by a high level of the power of the lower limbs, which perform the basic driving function; body 
height, on which the technique of covering the road may depend, and a different function of the upper limbs. These factors are the basic determinants predisposing competitors to this type of climbing (Guo, Wang, Liu, \& Hanson, 2019; Krawczyk, Ozimek, \& Pociecha, 2015; Krawczyk et al., 2017; Krawczyk \& Ozimek, 2014; Shulga, 2014). The assessment of the level of the anaerobic performance of the lower limbs of young speed climbers of both sexes in our own research demonstrated its higher level in older age categories and its high correlation with the results in younger age categories. In the light of the available literature, it can be concluded that attempts to assess the motor efficiency of young speed climbers were rarely made. As has already been mentioned, the exception was Shulga (Shulga, 2010), where, among others, attempts were made to assess the explosive strength of the lower limbs, 2-cm hang board training and clamping the dynamometer. In these studies, high correlations between motor efficiency and climbing time were also noted in the following areas: dynamometer clamping force (rxy = -0.53); long jump ( $r x, y=-0.53$ ); vertical jump ( $r x, y=-0.9)$ and the hang board pull-up test (rx, $y=-0.69$ ). These results indicate the importance of speed and strength capabilities in achieving good climbing times in speed climbing and confirm the results of our own research. In addition, the results of our own research are consistent with the results of other authors' research on the importance of the lower limbs and the level of anaerobic potential in achieving high sports results in speed climbing (Krawczyk, Ozimek, \& Pociecha, 2015; Krawczyk et al., 2017). In view of the small amount of data in the world literature regarding the anaerobic potential of the lower limbs of young speed climbers as measured by means of the Wingate test, a suggestion can be made that the results of this study may constitute reference values and should be reviewed in the future.

In own research, an attempt was made to answer the question about the nature of the correlations between the results of the Wingate test and the best time of the climbing race. The results of the evaluation of these correlations are presented in Table 2. These results indicate that in the groups of boys the power peak (PP [W / kg]), i.e. the level of speed ability, is not the most important factor determining climbing time and that the strength of the correlation of this factor decreases with an increase in training experience. A significant correlation of the power peak index (PP [W / kg]) was observed in the F2 group (younger age category), with a similar decrease in the strength of this factor in the higher age category as in boys. Note should also be made of the correlation of the relative indicator $\mathrm{W}_{\text {tot }}[\mathrm{J} / \mathrm{kg}]$, which informs about the level of development of maximum lactic acid power. In the groups of girls, the strength of the correlation of this indicator with climbing time was significant, with a higher correlation found in the $\mathrm{F} 1$ group. In the boys' groups, the strength of $\mathrm{W}_{\text {tot }}$ and climbing time correlation was lower, but similarly to girls, the strength of the correlations was higher in the older age group M1. The assessment and analysis of our own results 
indicate that in speed climbing, along with an increase in traineeship or sports level, the hierarchy of factors determining the achievement of high results in the race undergoes a change. It seems that in the groups of younger girls the speed potential is the basic factor that significantly determines the result of a race. However, in the older category of girls, the result of the race is determined by a larger set of individual predispositions, and in addition to the speed potential (ability to develop maximum acidic strength), it seems that the level of coordination of predispositions and motor skills (movement technique) will be important. The other factor is associated with greater sports traineeship and experience. In the boys' groups, similar, and even larger in scope, regularities were observed indicating that, in addition to speed and strength factors, high sporting performance is also influenced by other important factors of motor potential.

In the light of the above considerations, it should be stated that the abovementioned generalizations, indicating that along with the passage of time and the increase of training period, a change occurs in the impact of factors determining the final effect of speed climbing. This statement is consistent with previous reports of other authors (Rokowski \& Tokarz, 2007) who pointed out that the higher the level of climbers' training practice, the less important the level of strength preparation is, and the result can be determined by a number of other (mental, tactical, technical etc.) factors. Moreover, the aforementioned authors asserted that at different levels of training the outcome and efficiency of climbing may be determined by a different set of motor factors.

Based on the results of our own research and analysis of the literature, the following conclusions were drawn:

1. Factors determining the result of speed climbing race are: power motor potential, coordination motor potential and movement technique, somatic predispositions, including body length dimensions and psychological predispositions.

2. Depending on the sporting experience, the set of factors determining the result of a climbing race is subject to change. The decreasing influence of the speed-force factor is accompanied by an increase in the importance of other factors, probably coordination motor factors, in achieving high sports results. The range of variability of the impact of these factors depends on the sex of the sportspeople under examination.

3. The result of a speed climbing race in various age categories is conditioned by a different set of motor factors.

4. Despite its non-specificity, the Wingate test can be used in recruitment and selection for speed climbing. The results of this test are the basis for assessing the level of the development of speed and strength capabilities and can be a reliable source of information for coaches. 
Krawczyk et al., 2020. Value of Speed Capabilities in Youth Speed Climbing at High Sports Level

\section{References}

Baláš, J., Strejcová, B., Malý, T., Malá, L., \& Martin, A.J. (2009). Changes in upper body strength and body composition after 8 weeks indoor climbing in youth. Isokinetics and Exercise Science, 17(3), 173-179. DOI: https://doi.org/10.3233/IES-2009-0350

Bozic, P.R., \& Berjan Bacvarevic, B. (2018). Force-Velocity Profiles of Elite Athletes Tested on a Cycle Ergometer. Montenegrin Journal of Sports Science and Medicine, 7(1), 5966. DOI: https://doi.org/10.26773/mjssm.180308

Carvalho, H.M., Silva, M.J.C.E., Figueiredo, A.J., Gonçalves, C.E., Philippaerts, R.M., Castagna, C., \& Malina, R.M. (2011). Predictors of maximal short-term power outputs in basketball players 14-16 years. European Journal of Applied Physiology, 111(5), 789796. DOI: https://doi.org/10.1007/s00421-010-1703-4

Guo, F., Wang, Q., Liu, Y., \& Hanson, N.J. (2019). Changes in blood lactate and muscle activation in elite rock climbers during a 15-m speed climb. European Journal of Applied Physiology, 119(3), 791-800. DOI: https://doi.org/10.1007/s00421-018-04070-w

Krawczyk, M., Ozimek, M., \& Pociecha, M. (2015). Poziom wybranych zdolności kondycyjnych i ich związek z wynikiem sportowym we wspinaczce na czas. In T. Gabryś \& A. Stanula (Eds.), Trening Sportowy I. Planowanie - kontrola -sterowanie. Państwowa Wyższa Szkoła Zawodowa im. rtm. Witolda Pileckiego w Oświęcimiu.

Krawczyk, M., Ozimek, M., \& Rokowski, R. (2015). Value of select displays of strength and speed abilities in speed climbing at the highest sport level - analysis of cases. In International Scientific Conference, Motor Ability in Sports - Theoretical Assumptions and Practical Implications. Kraków.

Krawczyk, M., Ozimek, M., Rokowski, R., Pociecha, M., \& Draga, P. (2017). Level of selected speed ability indexes of lower limb in relation on climbing time in speed climbing. In The Second International Scientific Conference Motor Abilities in Sports - Theoretical Assumptions and Practical Implications. Institute of Sports, University of Physical Education in Krakow.

Krawczyk, M, \& Ozimek, M. (2014). Somatic traits and motor skill sbilities in top-class professional speed climbers compared to recreational climbers. Kinesiology, 25(66), 2532. DOI: https://doi.org/10.5604/17310652.1149298

Krawczyk, M., Ozimek, M., Rokowski, R., Pociecha, M., \& Draga, P. (2018). Anthropometric characteristics and anaerobic power of lower limbs and their raltionships with race time in female climbers. Society. Integration. Education. Proceedings of the International Scientific Conference., IV, 118-126. DOI: https://doi.org/10.17770/sie2018vol1.3268

Levernier, G., Pierre, S., \& Laffaye, G. (2020). Force-Velocity-Power profile in high elite boulder, lead, speed, climbers competitors. International Journal of Sports Physiology and Performance.

Magiera, A., Roczniok, R., Maszczyk, A., Czuba, M., Kantyka, J., \& Kurek, P. (2013). The structure of performance of a sport rock climber. Journal of Human Kinetics. DOI: https://doi.org/10.2478/hukin-2013-0011

Mermier, C.M., Janot, J.M., Parker, D.L., \& Swan, J.G. (2000). Physiological and anthropometric determinants of sport climbing performance. British Journal of Sports Medicine. DOI: https://doi.org/10.1136/bjsm.34.5.359

Michailov, M.L., Mladenov, L.V., \& Schoeffl, V. (2009). Anthropometric and strength characteristics of world-class boulderers. Medicina Sportiva, 13(4), 231-238.

Michailov, M.L., Morrison, A., Ketenliev, M.M., \& Pentcheva, B.P. (2015). A sport-specific 
upper-body ergometer test for evaluating submaximal and maximal parameters in elite rock climbers. International Journal of Sports Physiology and Performance, 10(3), 374380. DOI: https://doi.org/10.1123/ijspp.2014-0160

Morrison, A.B., \& Schoffl, V.R. (2007). Physiological responses to rock climbing in young climbers. British Journal of Sports Medicine, 41(12), 852-861. DOI: https://doi.org/ 10.1136/bjsm.2007.034827

Nichols, J., Wing, D., Bellicini, Z., Bates, R., Hall, D., Hall, D., ... Shen, J. (2018). ClimbingSpecific Fitness Profiles and Determinants of Performance in Youth Rock Climbers. Journal of Sports Science, 6(5). DOI: https://doi.org/10.17265/2332-7839/2018.05.001

Nikolaidis, P., Afonso, J., Buśko, K., \& Ingebrigtsen, J. (2015). Positional Differences of Physical Traits and Physiological Characteristics in Female Volleyball Players - the Role of Age. Kinesiology, 47(1), 75-81.

Nikolaïdis, P.T. (2012). Age-related differences in force-velocity characteristics in youth soccer. Kinesiology, 44(2), 130-138.

Ozimek, M., Krawczyk, M., Zadarko, E., Barabasz, Z., Ambrozy, T., Stanula, A., ... Mucha, D. (2017). Somatic Profile of the Elite Boulderers in Poland. Journal of Strength and Conditioning Research, 31(4), 963-970. DOI: https://doi.org/10.1519/JSC.00000000 00001673

Ozimek, M., Rokowski, R., Draga, P., Ljakh, V., Ambroży, T., Krawczyk, M., ... Mucha, D. (2017). The role of physique, strength and endurance in the achievements of elite climbers. PLoS ONE. DOI: https://doi.org/10.1371/journal.pone.0182026

Rokowski, R., \& Tokarz, R. (2007). Znaczenie zdolności motorycznych o podłożu enegretycznym we wspinaczce sportowej w konkurencji na trudność w stylu on-sight. Anatropomotoryka - Journal of Kinesiology and Exercise Sciences, 40, 81-91.

Shulga, O. (2010). Fizichna Pidgotovlenist Sportsmenic 14-15 Rokiv, Jaki Specializjut Sja U Shvidkisnomu Lazinni. Aktualni Problemi Fizichnoï Kulturi i Sportu, 18(2), 30-35.

Shulga, O. (2014). Model characteristics of athletes-climbers specializing in speed climbing (format record). Sport Science of Ukraine, 59(1), 14-18.

Stewart, A., Marfell-Jones, M., \& International Society for Advancement of Kinanthropometry. (2011). International standards for anthropometric assessment (2011 ed.). Lower Hutt New Zealand: International Society for the Advancement of Kinanthropometry.

Tomaszewski, P., Gajewski, J., \& Lewandowska, J. (2011). Somatic profile of competetive sport climbers. Journal of Human Kinetics, (29), 107-113. DOI: https://doi.org/10.2478/ v10078-011-0044-7

Votava, J., Matej, D., Otahal, M., \& Kutilek, P. (2018). Predictors of boulder climbing performance in youth boulder climbers. 36th Conference of the International Society of Biomechanics in Sports, Auckland, New Zealand, 662-665.

Watts, P.B. (2004). Physiology of difficult rock climbing. European Journal of Applied Physiology, 91(4), 361-372. DOI: https://doi.org/10.1007/s00421-003-1036-7

Watts, P.B., Joubert, L.M., Lish, A.K., Mast, J.D., \& Wilkins, B. (2003). Anthropometry of young competitive sport rock climbers. British Journal of Sports Medicine, (37), 420-424.

Watts, P.B., \& Ostrowski, M.L. (2014). Oxygen Uptake and Energy Expenditure for Children during Rock Climbing Activity. Pediatric Exercise Science, 26(1), 49-55. DOI: https://doi.org/10.1123/pes.2013-0035 